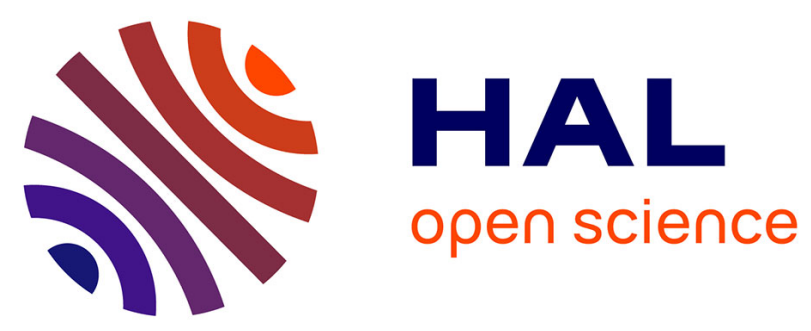

\title{
Invasion of a Sphagnum-peatland by Betula spp and Molinia caerulea impacts organic matter biochemistry. Implication for carbon and nutrient cycling.
}

Sébastien Gogo, Fatima Laggoun-Défarge, Frédéric Delarue, Nathalie Lottier

\section{- To cite this version:}

Sébastien Gogo, Fatima Laggoun-Défarge, Frédéric Delarue, Nathalie Lottier. Invasion of a Sphagnumpeatland by Betula spp and Molinia caerulea impacts organic matter biochemistry. Implication for carbon and nutrient cycling.. Biogeochemistry, 2011, 106 (1), pp.53-69. 10.1007/s10533-010-9433-6 . insu-00419696

\section{HAL Id: insu-00419696 \\ https://hal-insu.archives-ouvertes.fr/insu-00419696}

Submitted on 16 Jun 2010

HAL is a multi-disciplinary open access archive for the deposit and dissemination of scientific research documents, whether they are published or not. The documents may come from teaching and research institutions in France or abroad, or from public or private research centers.
L'archive ouverte pluridisciplinaire HAL, est destinée au dépôt et à la diffusion de documents scientifiques de niveau recherche, publiés ou non, émanant des établissements d'enseignement et de recherche français ou étrangers, des laboratoires publics ou privés. 
Invasion of a Sphagnum-peatland by Betula spp and Molinia caerulea impacts on organic matter biochemistry. Implications for carbon and nutrient cycling.

Sébastien Gogo, Fatima Laggoun-Défarge, Frédéric Delarue, Nathalie Lottier Université d’Orléans, Université François Rabelais - Tours, CNRS/INSU. Institut des Sciences de la Terre d’Orléans

Université d'Orléans, Université François Rabelais - Tours, CNRS/INSU. Institut des Sciences de la Terre d’Orléans 1A rue de la Férollerie 45071 Orléans Cedex 2

France

Tel : 0033238494502

Fax : 0033238636488

sebastien.gogo@univ-orleans.fr 


\section{KEYWORDS}

Carbon substrate injection, elemental analysis, Organic matter sources and decay, Pyrophosphate Index, Rock Eval pyrolysis, sugars

\section{Abstract}

Peatlands act as a sink of carbon (C) through the accumulation of dead remains of plants. Under global changes triggered by human activities, it is not only the sink capacity of peatland that is in danger, but also the $\mathrm{C}$ already stored. Invasion of Sphagnum peatlands, mainly by Molinia caerulea and Betula spp, is a growing preoccupation. This study aims to assess the extent of the influence of this invasion on the biochemical characteristics of the peat. Elemental analysis, sugar and Rock Eval pyrolysis parameters were measured in $50 \mathrm{~cm}$ profiles collected in invaded and intact plots. The results show that oxygen index ratios $\left(\mathrm{OICO}_{2} / \mathrm{OICO}\right)$ can be used to detect new $\mathrm{C}$ substrate injection as invading plants have a lower ratio than Sphagnum spp and Sphagnum peat. Total hemicellulosic sugar contents and OM degradation indices (R400, PPI) suggest that the invading plants promote a faster OM decomposition probably through a faster degradability and a relatively higher nutrient content of their litter. Differences in terms of nutrient status between areas of the peatland are suggested to be of great importance in determining the extent of $\mathrm{OM}$ transformation likely due to stoichiometric constraints. 


\section{INTRODUCTION}

Plants considered as engineer species are able to create and sustain conditions that are suitable for their own growth and expansion by modulating the availability of resources to other species (Jones et al, 1994). Sphagnum species, by regulating the availability of Nitrogen $(\mathrm{N})$, producing a recalcitrant litter and by creating conditions unfavorable to other organisms (decreasing $\mathrm{pH}$ and micronutrient availability) are one such engineer species (van Breemen, 1995). Under increased N deposition (Tomassen et al, 2003; Tomassen et al, 2004), Sphagnum may lose its engineering capabilities, making Sphagnum peatlands susceptible to invasion by vascular plants, mainly Molinia caerulea and Betula spp. Vascular plants act on the soil Organic Matter (OM) quantity and quality through their litter and their roots. For nutrients such as $\mathrm{N}$ and Phosphorus (P), litterfall is the dominant pathway to return to the soil (Schlesinger, 1997). Roots through the death of their tissues and their exudates are major contributors to $\mathrm{C}$ and nutrient cycling (Fontaine et al, 2007).

During the development of ecosystems, soil pH decreases and C content increases (Ford, 1990; Charman, 2002). Allogenic changes, such as soil exploitation for agriculture, leads to a decrease in soil C content (Schlesinger, 1997). Nowadays, human activities trigger vegetation changes in ecosystems. Knowing how such changes will affect the soil $\mathrm{C}$ quantity and quality is of uttermost importance in the context of climate change: depending on the direction of the $\mathrm{C}$ flux induced, the vegetation changes may increase or buffer greenhouse gas concentrations in the atmosphere (Cornelissen et al, 2007). Peatlands, which contain a third of the

world soil C (Gorham, 1991), are among the ecosystems that undergo vegetation change because of human activity. $\mathrm{N}$ supply to peatlands has been demonstrated 
to stimulate the growth of invading species such as Betula pubescens and Molinia caerulea (Tomassen et al, 2004). It has also been shown that the presence of Molinia caerulea decreases the growth of Sphagnum species (Hogg et al, 1995), which are the main peat-forming species. Considering that Molinia caerulea is $\mathrm{N}$ limited and that $\mathrm{N}$ deposition is high in Europe, invading species may expand in peatlands at the expense of Sphagnum species, which would imply a decrease in the C sink capacity of such systems. In addition, the vascular plants, because of their higher nutrient content may produce a litter that decomposes more rapidly than that of Sphagnum species (Clymo and Hayward, 1982, Comont, 2006, Coulson and Butterfield, 1978), potentially leading to an increased rate of C and nutrient mineralization, which may sustain the development of the invading species. Furthermore, in the form of root exudates, vascular plants can inject labile $\mathrm{C}$ source in deep peat layers. In peatlands, the lack of labile $\mathrm{C}$ source is a factor limiting microbial activity (Bergman et al, 1998).

The aim of this study is to assess how the recent invasion of a Sphagnum peatland by Betula spp. and Molinia caerulea affects the soil OM dynamics. Rather than the separate effects of the different colonizing species, it is the global effect of vascular plant colonisation of the peatland that is tested here. Bulk organic geochemical analyses (elemental and carbohydrate composition, Rock-Eval pyrolysis) were used to compare peat from intact and colonised plots. As nutrient availability may be an important factor controlling soil processes, analyses of surface peat water and of an incoming drain were performed. Bulk organic geochemical analyses have proved to be efficient in revealing both the botanical origin of the $\mathrm{OM}$ and the degradation processes that these precursors undergo in lake sediments (Jacob et al, 2004), marine sediments (Knies, 2005), mineral soils 
(Disnar et al, 2003) and peat profiles (Bourdon et al, 2000; Comont et al, 2006; Laggoun-Défarge et al, 2008). Thus, in the present report, some of these techniques were used to compare the biochemical composition of OM from areas colonised by the invading vascular plants versus intact areas of a peatland.

\section{MATERIAL, SAMPLING AND METHODS}

\section{Study site}

The site studied is La Guette peatland (154m, 47'19' North and $2^{\circ} 14^{\prime}$ East) located in the south-eastern part of the French Centre Region (Neuvy-surBarangeon, Cher). The mean annual precipitation and temperature is $883 \mathrm{~mm}$ and $11^{\circ} \mathrm{C}$ respectively (for the period 1989-2001). It is a transitional fen (pH about 4 , [Ca] $>$ [Mg], Table 1) that has been invaded by Molina caerulea and Betula spp (Betula verrucosa and Betula pubescens) for 30 years with an acceleration of the invasion in the last decade. The dominant moss species are Sphagnum cuspidatum and Sphagnum rubellum. A drain connected to the eastern part of the peatland intermittently discharges water directly into the peatland (Figure 1). The chemical composition of water collected on May 2008 from this drain is given in Table 2. Surface water from the studied plots (see below) was collected seasonally (May 2008, September 2008, December 2008 and March 2009). Their characteristics are presented in Table 1.

Table 1.

Figure 1.

Table 2. 


\section{Experimental design and core sampling}

The peatland was divided into two areas. It can be assumed that the two sub-areas of the peatland (West area and East area) were colonised relatively independently. The East area differs from the West area by a lower water table. The water table varied between $-5.5 \mathrm{~cm}$ and $-26 \mathrm{~cm}$ below the vegetation in the West area, and between $-5.5 \mathrm{~cm}$ and $-40 \mathrm{~cm}$ in the East area (period from September 2008 to December 2009). Differences in the water table occurred mainly during the summer. These differences may be caused by higher altitude and/or water works near the peatland, and by a periodic supply of water rich in nutrients such as $\mathrm{K}$ from the drain (unpublished data). To distinguish the two areas in relation to their hydrology, the West area is referred to as Wet and the East area as Dry.

To test differences 1) between plots with different vegetation, 2) between areas from different hydrological areas, and 3) in vegetation-area interaction, two areas were considered: the Wet area (named W) and the Dry area (named D), and within each area, an intact plot (named O for open vegetation) and a colonised plot (with both Betula spp and Molinia caerulea, named C for closed vegetation) were chosen. The location of each sampling plot, WO, WC, DO and DC, the characteristics of their surface water and their vegetation are reported in Figure 1 and Tables 1 and 3, respectively.

On June 2008, four cores (50 cm long) were collected with a Russian corer in each vegetation situation (open and closed), in each area of the peatland (Wet and Dry), within plots of a $4 \mathrm{~m}^{2}$ surface area (total of 16 cores). This surface was chosen to limit spatial heterogeneity and because totally intact areas were small. Most cores were collected in Sphagnum habitats in both open and closed vegetation. The litter of vascular plants was not included in the cores. Sphagnum 
species have no litter in the sense used for vascular plants. As assumed by most litter bag studies, the litter compartment of Sphagnum refers to the segment below the photosynthetic part and above the dark brown part (Bragazza, 2008). The top of the cores corresponded to the level where Sphagnum litter becomes brown (Figure 2). The trees (Betula spp) in the wet area were cut down by the manager in 2002, but they remained alive and tillers are now growing up to $3 \mathrm{~m}$. In the dry area, intact tall stands (15m) of Betula spp are present. In the laboratory, the cores were frozen until processing. After defreezing, they were cut into 10 sections each $5 \mathrm{~cm}$ long (Figure 2). Roots which were present at all depths of the cores were removed. The samples were dried at $50^{\circ} \mathrm{C}$ and crushed with an annular grinder. Dry weight was measured after drying to assess the bulk density. The different analyses were then conducted.

Figure 2.

Table 3.

\section{Organic Matter (OM) content}

The crushed peat (100 mg) was weighed in a crucible, placed in an oven and burnt at $550^{\circ} \mathrm{C}$ during 4 hours. As peat contains mostly $\mathrm{OM}$ and as la Guette peatland is acidic (no carbonates present), the mass loss on ignition was considered to be only OM (expressed in \% of dry weight).

\section{Carbon (C), Nitrogen (N) and Sulfur (S) content analysis}

C, $\mathrm{N}$ and S analysis was determined by combustion of dried and crushed samples at $1100^{\circ} \mathrm{C}$, using a CNS-2000 LECO apparatus. 


\section{Rock-Eval pyrolysis}

The Rock-Eval technique was primarily developed to diagnose oil-producing hydrocarbon (HC) source rocks by measuring the ratio of the amount of Hydrogen and Oxygen cracked during the pyrolysis cycle to the Total Organic Carbon (Hydrogen Index $=$ HI, and Oxygen Index = OI respectively) and by determining the temperature of maximum hydrocarbon cracking (Espitalié et al., 1985; Lafargue et al., 1998). The technique was further adapted to assess the biochemical quality of soil OM. Disnar et al (2003) showed that Rock-Eval parameters can reveal the chemical evolution of the OM during the process of humification. Rock-Eval parameters were used here to assess OM quality between plots with different vegetation and from the two hydrological areas.

The analyses were carried out on 30 mg of powdered dry peat with a "Turbo"' Rock-Eval $6^{\circledR}$ pyrolyser manufactured by Vinci ${ }^{\circledR}$ Technologies (Espitalié et al., 1985; Lafargue et al., 1998). Briefly, the samples were first pyrolysed under inert atmosphere $\left(\mathrm{N}_{2}\right)$, and the residual $\mathrm{C}$ was subsequently burnt in an oxidation oven. The amount of HC released during pyrolysis was detected by a flame ionisation detector, while online infrared detectors continuously measured the released CO and $\mathrm{CO}_{2}$. The standard pyrolysis program started with an isothermal stage of 2 $\min$ at $200^{\circ} \mathrm{C}$. The pyrolysis oven temperature was then raised to $650^{\circ} \mathrm{C}$ at $30^{\circ} \mathrm{C}$ $\min ^{-1}$, and held for $3 \mathrm{~min}$ at this temperature. The oxidation phase started at an isothermal stage at $400^{\circ} \mathrm{C}$, followed by an increase to $850{ }^{\circ} \mathrm{C}$ at $30^{\circ} \mathrm{C} \mathrm{min}^{-1}$ and held at this final temperature for 5 min. Rock-Eval parameters were calculated by integration of the amounts of $\mathrm{HC}, \mathrm{CO}$ and $\mathrm{CO}_{2}$ produced during the thermal cracking of the OM, between well-defined temperature limits. Our work focused 
on the following parameters derived from signals recorded during the pyrolysis and oxidation phases:

- $\mathrm{HI}=$ Hydrogen Index (mg $\mathrm{HC} \mathrm{g}^{-1} \mathrm{TOC}$ ) corresponds to the quantity of $\mathrm{HC}$ released during pyrolysis relative to TOC, namely S2/TOC.

- $\mathrm{OICO}_{2}=\mathrm{CO}_{2}$ Oxygen Index $=\left(\mathrm{mg} \mathrm{CO}_{2} \mathrm{~g}^{-1} \mathrm{TOC}\right)$ corresponds to the quantity of $\mathrm{CO}_{2}$ released during pyrolysis, relative to TOC.

- OICO = CO Oxygen index (mg CO g $\left.{ }^{-1} \mathrm{TOC}\right)$ corresponds to the quantity of CO released during pyrolysis, relative to TOC.

- OIRe6 = Rock-Eval 6 Oxygen Index (mg $\mathrm{O}_{2} \mathrm{~g}^{-1}$ TOC) corresponds to the quantity of oxygen released as $\mathrm{CO}$ and $\mathrm{CO}_{2}$ during pyrolysis, relative to TOC.

- $\mathrm{OICO}_{2} / \mathrm{OICO}$ parameter is the ratio of the amount of pyrolysed $\mathrm{CO}_{2}$ to the amount of pyrolysed CO.

- R400 parameter is the ratio of the part of the S2 signal produced below $400^{\circ} \mathrm{C}$ to the total S2 signal. It corresponds to an index of OM transformation as it results from the thermal decomposition of biological compounds such as cellulose and lignin before $400^{\circ} \mathrm{C}$, and humic substances after $400^{\circ} \mathrm{C}$ (Disnar et al., 2003; Sebag et al., 2006; Disnar et al., 2008).

\section{Pyrophosphate index (PPI)}

The pyrophosphate index (Kaila, 1956) was calculated following Gobat et al (1986). The humic compounds of peat $(0.5 \mathrm{~g})$ were extracted with a sodium pyrophosphate at $0.025 \mathrm{M}$ overnight. The mixtures were filtered (Whatman 2V) and the filtrates were completed with deionised water to $250 \mathrm{ml}$. The optical density of the solution was measured at $550 \mathrm{~nm}$ with a spectrophotometer 
(Shimadzu). The pyrophosphate index was obtained by multiplying the optical density measured by 100 .

\section{Neutral monosaccharide analyses}

Hemicellulosic content measurement has been described elsewhere (Comont et al, 2006; Disnar et al, 2008). Briefly, a dry peat sample was hydrolysed with diluted $\mathrm{H}_{2} \mathrm{SO}_{4}$ at $100^{\circ} \mathrm{C}$ overnight. The extract was neutralized, centrifuged and evaporated. Monosaccharides were 1) extracted with methanol, which was then evaporated, 2) diluted in pyridine, 3) derivated with N,O-bis(trimethylsilyl)trifluoroacetamide (BFTSA) before the injection into a GC (Perkin-Elmer, FID). Deoxyglucose was used as an internal standard.

\section{Statistical analyses}

Two-way factorial ANOVAs were conducted for each variable at each depth to test for differences between plots with different vegetation, areas with different hydrology and for interaction between vegetation and hydrology. Normality of residues and variances homogeneity were tested (Kolmogorov and Smirnov test and Levene test, respectively). Data were transformed to improve the ANOVA assumptions fulfillment (log, square root or inverse). The Pearson product moment correlation was used to test for correlation. The level of significance of all tests was set to $P<0.05$. Statistica (Statsoft 2008) was used to conduct the tests.

\section{RESULTS}


Results of whole cores showed that the depth of peat differed between the sampling plots (Table 4). In the lower part of the cores $(35-50 \mathrm{~cm})$, the degree of humification (PPI) varied within a given area, whereas in the middle part (15-35 $\mathrm{cm}$ ) the differences between areas were more marked (Table 4A). This shows that peat from the lower and the middle part of the cores had different ages and experienced dramatic differences in terms of source materials (depending on the stage of development, a peatland exhibits different types of vegetation) and degradation conditions. However, PPI, C, N and S peat contents tended to converge toward the top of the core (Table 4A), suggesting that source materials and degradation conditions in all plots became more similar. Analyses and discussion were carried out only on peat from the first three depths so as to compare peat with ages that were as similar as possible.

Statistical analyses on the first three depths showed that there was only one significant vegetation and area interaction, on the bulk density (Table 5). This interaction was much less significant than the two main effects (at least one order of magnitude, Table 5). Thus, for bulk density as well as for all the other factors, only the main effects were considered.

From the statistical results (Table 5), the response variables could be separated into four groups. The first group was composed of variables exhibiting differences between plots with different vegetation and from different areas of the peatland, at the same depth or at different depths: bulk density, PPI, HI, total hemicellulose (Table 5, Figure 3). The second group showed differences only between plots with different vegetation: OIRe6 and $\mathrm{OICO}_{2} / \mathrm{OICO}$ (Table 5, Figure 4). The third group showed differences between peatland areas: R400, C/S ratio (Table 5, Figure 5) and S content (Table 5). The fourth group was composed of variables 
showing no or insignificant differences: $\mathrm{C} / \mathrm{N}$ ratio, $\mathrm{OM}$ content, $\mathrm{C}$ and $\mathrm{N}$ content (Table 5).

Table 4

Table 5

\section{Variables affected by the vegetation and the areas of the peatland}

At all depths, the colonizing vegetation significantly increased the peat bulk density compared to the intact vegetation (Figure 3a, b, c). Also, other than at the surface, the peat was denser in the Wet area than in the Dry area.

At the surface, the peat was more decomposed (higher PPI) in closed vegetation plots than in open ones and no differences were observed between hydrological areas (Figure 3d). However, at the depth of 10-15 cm, the opposite was observed: the peat was more decomposed in the Wet area than in the Dry area and no differences were revealed with vegetation (Figure 3f). In between $(5-10 \mathrm{~cm})$, the peat showed the same degree of decomposition in all plots (Figure 3e).

At all depths, total hemicellulose was measured in significantly higher concentrations in the Dry area than in the Wet area (Figure 3g, h, i). Peat hemicellulosic content was higher in the open vegetation plots only at the surface (Figure 3g).

Figure 3

Variables affected by the vegetation 
At all depths, both OIRe6 and $\mathrm{OICO}_{2} / \mathrm{OICO}$ ratios were higher in the plots with open vegetation than in those with closed vegetation (Figure 4). OIRe6 tended to decrease with depth in both plots, whereas $\mathrm{OICO}_{2} / \mathrm{OICO}$ remained constant (Figure 4).

Figure 4

\section{Variables affected by the hydrology of the peatland}

The R400 (Figure 5a, b, c) and the S content were lower in the Wet area of the peatland than in the Dry area. The differences in $S$ contents explain the differences observed in the C/S ratio (Figure $5 d, e, f$ ) as the $C$ content showed no significant differences (Table 5).

Figure 5

\section{Variables showing no significant differences}

Other than the $\mathrm{C} / \mathrm{N}$ ratio at $10-15 \mathrm{~cm}, \mathrm{C} / \mathrm{N}$ ratio, $\mathrm{C}, \mathrm{N}$ and $\mathrm{OM}$ contents did not differ between plots (Table 5). OM contents at depths 5-10 cm and 10-15 cm were highly similar between plots with different vegetation (both $P>0.88$ ), but at the surface, the level of significance decreased by an order of magnitude $(P=0.08)$, without being significant at the level set previously.

\section{Rock-Eval indices: $\mathrm{R400}$ and $\mathrm{OICO}_{2} / \mathrm{OICO}$}

Rock Eval indices are more widely used for oil-producing rocks and petroleum reservoir studies. However, these indices, especially R400, have also proved to be 
valuable in characterizing a wide range of soils and in studying processes such as humification (Disnar et al, 2003). Hemicellulose is a part of fresh unmodified OM. Our results on peat from 0 to $15 \mathrm{~cm}$ depth show that the R400 index was positively correlated with the amount of hemicellulose $(\mathrm{R}=0.76, P<0.001, \mathrm{n}=$ 48, Figure 6).

Figure 6

In order to highlight the influence of botanical sources on the resulting peat biochemistry, litter from the dominant precursors of the undisturbed peatland (Sphagnum cuspidatum and Sphagnum rubellum) and those from the two dominant species invading the peatland (Molinia caerulea and Betula verrucosa) were analysed (Table 6). By comparing the precursors' biochemical characteristics to the peat composition, markers of sources were expected to be found. All oxygen indices (OI) measured by Rock Eval pyrolysis varied greatly between plants (Table 6). Figure 7 shows that OICO did not discriminate the different source materials. In contrast, $\mathrm{OICO}_{2}$ was a good parameter to separate Sphagnum spp. and vascular plant litters. However, the roots of Betula verrucosa and Molinia caerulea presented $\mathrm{OICO}_{2}$ values closer to that of Sphagnum spp. than their aboveground counterparts. The $\mathrm{OICO}_{2} / \mathrm{OICO}$ ratio was found to discriminate vascular plants (litter and roots) well from Sphagnum species (Table 6). Above- and belowground parts of vascular plants exhibited similar ratios (between 1 and 2), lower than the Sphagnum ratio (above 3).

Table 6. 
Figure 7.

DISCUSSION

\section{Relevance of indices from Rock-Eval pyrolysis in assessing peat biochemistry} R400

Hydrocarbons from living vegetation and litter, mainly composed of lignocellulosic compounds, are cracked early during the temperature rise of the Rock Eval pyrolysis cycle (mostly before $400^{\circ} \mathrm{C}$ ). In contrast, transformed OM such as humic substances resulting from the biological and chemical degradation of fresh litter is cracked later (mostly after $400^{\circ} \mathrm{C}$ ). Thus, the R400 index reflects the relative abundance of fresh unmodified OM (Disnar et al, 2003) and can be considered as an indicator of OM transformation. While R400 has been used successfully to reveal humification processes in forest soils (Disnar et al, 2003), this has not so far been undertaken with peat soils. In the process of OM degradation, fresh organic compounds such as hemicellulose are decomposed and transformed by the soil biota. This results in a loss in the polysaccharide content of peat, which would be revealed by a decrease in R400. In our case, this was confirmed by the significant positive correlation between R400 and the peat hemicellulose content (Figure 6). This result suggests that the R400 index could be used in peat material in the same way as it has been used in mineral soil.

\section{$\mathrm{OICO}_{2} / \mathrm{OICO}$}

In the case of this study, the $\mathrm{OICO}_{2} / \mathrm{OICO}$ ratio was found to be the most appropriate index to separate Sphagnum material from both above- and 
belowground vascular plant material. Jacob (2003) suggested that in lacustrine sediments a high $\mathrm{OICO}_{2} / \mathrm{OICO}$ ratio may reflect input of well preserved initially oxygen-rich material. Such conditions were fulfilled in the present study. First, Sphagnum mosses were richer in oxygen than vascular plant organs (see values of oxygen indices in Table 6). Second, Sphagnum mosses create conditions favorable for the preservation of OM through the combined action of their soluble and bound polysaccharides (sphagnan) that bind nutrients and release $\mathrm{H}^{+}$(Clymo, 1967, Painter, 1991) and their polyphenolic networks and lipid coating that protect cell walls (van Breemen, 1995). These conditions of high oxygen content and good preservation conditions were suitable for using the $\mathrm{OICO}_{2} / \mathrm{OICO}$ ratio as a possible index of source materials.

\section{Impact of vascular plant invasion on OM biochemical quality}

Injection of labile OM in the peat profile

The $\mathrm{OICO}_{2} / \mathrm{OICO}$ ratio of Sphagnum litters was similar to those found in the surface peat of Open plots ( 3.4), probably reflecting the deposition and preservation of Sphagnum litter. However, the ratios of surface peat from Closed plots were intermediate between those of vascular plants and Sphagnum species. As roots were removed from peat samples these results suggest that root materials (dead roots and root exudates) contributed to the formation of the peat in Closed plots. Thus, differences in $\mathrm{OICO}_{2} / \mathrm{OICO}$ ratios may reflect the injection of labile OM into peat. Molinia caerulea produces a very extensive root system that can reach $80 \mathrm{~cm}$ in depth (Taylor et al, 2001). This injection of fresh OM not only occurred at the surface but may also occur in deeper layers of the peat profile as suggested by differences observed between open and closed vegetation plots in 
both dry and wet areas of the peatland (Table 4). Fontaine et al (2007) showed that in mineral soils this injection of root materials can lead to an increase in the mineralization of deep recalcitrant $\mathrm{C}$ through a priming effect. They pointed out that such an effect may not occur in wetlands as anaerobic conditions may overrule it. These authors, however, did not take into account the fact that water level fluctuates and peat as deep as $15 \mathrm{~cm}$ can be temporarily exposed to aerobic conditions. Furthermore, in cases of vascular plant invasion, oxygen can be directed to deep layers at the root-soil interface (Conrad, 1996). None of the parameters measured in this study can assess for the occurrence of a priming effect, but the results obtained encourage further studies in this direction.

\section{New litterfall quality and OM decomposition}

Surface peat from Closed plots (wet and dry pooled together) contained less hemicellulosic sugars than Open plots (wet and Dry pooled together) (Figure 3g), reflecting higher OM degradation (Comont et al, 2006). Deeper in the profile, such differences between plots with different vegetation were not observed (Figure 3h, i). Moreover, PPI showed that the surface peat from the Closed plots was more decomposed than the peat from the Open plots, irrespective of the hydrological status of the peatland. The increased decomposition in closed vegetation plots was supported by water analyses (Table 1). Dissolved organic carbon (DOC) concentration and conductivity were higher in closed than in open vegetation. These results suggest that the vascular plant invasion of the Sphagnum peatland increased OM decomposition. Furthermore, compared to Sphagnum species, Molinia caerulea and Betula spp have higher litter decomposability 
(Chamie and Richardson, 1978; Bartsch and Moore, 1985; Berendse, 1998). This would explain the results obtained.

Increased OM decomposition in closed plots as suggested would result in a decrease of OM content, but the results showed that there were no significant differences between plots at the level of significance set $(P<0.05)$. However, there was a trend of lower OM content in peat from closed plots toward the surface $(P<0.1)$, which supports higher decomposition in closed plots than in open plots.

Bulk density showed almost significant differences in all cases (Figures 3a, b, c), suggesting that this variable integrates the physico-chemical effect of both vascular plants and hydrologic differences between areas. The bulk density was significantly higher in the closed plots than in the open ones. Minkkinen and Laine (1998a) showed in pine mires that drainage first increases the peat bulk density, then increases $\mathrm{OM}$ decomposition, and finally, the pressure of the growing trees further compacts the peat. Thus, the high bulk density in La Guette closed plots could be attributed to the development of the root system of trees. Simultaneously, despite a lower water table in the Dry area than in the Wet area, the peat from 5 to $10 \mathrm{~cm}$ deep was denser in the Wet area than in the Dry area. Thus the drainage effect may not be sufficient to impact peat physico-chemistry in the way suggested by Minkkinen and Laine (1998a).

Increased OM decomposition can also produce denser peat, without necessarily decreasing the C content (Minkkinen and Laine, 1998b). The hemicellulosic sugar content and R400 results actually suggest a higher OM degradation in the wet area of the peatland. Moreover, no significant differences in C content were observed 
between plots. It is thus argued that the difference in terms of OM degradation between wet and dry areas would lead to denser peat in the wet area.

\section{Impact of the incoming drain on OM decomposition}

The differences in peat hemicellulosic sugar contents and R400 index between peatland areas (higher in the Dry area) suggest that OM was better preserved in the dry area. As the water table was lower in the latter area, resulting in longer aerobic periods that would promote OM decomposition, these results are puzzling. A possible explanation may come from the fact that this area of the peatland intermittently receives nutrients from a drain flowing directly into the peatland at this location (Figure 1, Table 2), which is not the case throughout the peatland. Soluble elements such as $\mathrm{K}$ and $\mathrm{S}$ had concentrations in surface water that decreased with distance from the drain (Figure 8). This could not be demonstrated with $\mathrm{N}$ as concentrations were below the detection limits in the samples measured. It was shown that the water within the peatland actually flows from the east to the west (Binet et al, personal communication). The dry area was thus richer in soluble nutrients than the wet area and this could be the result of nutrient inputs from the drain.

Figure 8.

Depending on the availability in mineral nutrients in the media, the microbial biomass may balance demand for mineral nutrients with consumption of supplementary $\mathrm{C}$ that would result in $\mathrm{C}$ overflow due to stoichiometric constraints (Manzoni and Porporato, 2009). From an experiment of wheat decomposition 
under nutrient-limiting conditions (in this case, N), Hadas et al (1998) hypothesized that the $\mathrm{C}$ that could not be mineralized to $\mathrm{CO}_{2}$ because of the lack of nutrients would flow into a "polysaccharide-like” pool. In the same way, in the wet area, which was poorer in mineral nutrients, such a process could occur, with polysaccharide consumption. The incomplete degradation of such material would result in the excretion of a transformed OM. In the dry area, where mineral nutrients were found in higher concentrations, less $C$ would need to be incorporated and less hemicellulose would flow into the "polysaccharide-like" pool, resulting in a better preservation of OM in this dry area than in wet nutrientpoor plots. The negative correlations between $\mathrm{C} / \mathrm{S}$ ratio in free water and the surface peat hemicellulose content (Figure 9a) and R400 (Figure 9b) support this hypothesis: for an equivalent amount of soluble C, more hemicellulose was degraded and more transformed OM was produced as the availability of S (less S for the same amount of C) decreased (Figure 9).

Figure 9.

In the wet area, where soluble S may be limiting, the microbial community may have found in the solid OM, i.e. peat, the amount of S required for its growth and thus rejected the excess $\mathrm{C}$ (C overflow) in the form of transformed OM. Manzoni and Porporato (2009) and Hadas (1998) based their argument of C overflow on models developed for mineral soils. From the results presented in Figure 9, although obtained with only 4 points, the hypothesis of $\mathrm{C}$ overflow under nutrient limiting conditions deserves to be tested on peat soils and La Guette peatland offers a good case of study. 


\section{CONCLUSION}

Rock Eval analysis on peat samples from La Guette peatland showed that R400 and the $\mathrm{OICO}_{2} / \mathrm{OICO}$ ratios were valuable indices to assess $\mathrm{OM}$ degradation and to discriminate litters of Sphagnum species from those of vascular plants, respectively. These indices were used to highlight differences between areas with different water levels and vegetation types in the peatland. The $\mathrm{OICO}_{2} / \mathrm{OICO}$ profiles showed that invading species through their roots may inject labile OM into deep peat. The R400, coupled to hemicellulosic sugar analyses, showed that OM was more decomposed in plots invaded by vascular plants. These results suggest that invasion of a peatland by vascular plants such as Betula spp and Molinia caerulea affected both surface and deep peat processes.

This study also highlights the important impact of the incoming drain on soil processes. It is suspected that the drain may have enriched the dry area of the peatland in nutrients that modified decomposition conditions in this area compared to the wet one. The microbial community in the dry nutrient-rich area may not have needed to decompose peat to cover its nutrient requirements. In contrast, in the wet nutrient poor area, microbes may have needed to consume more C substrates with the production of a polysaccharide-like pool, i.e. more transformed OM.

All these conclusions obtained with bulk peat analyses could be supported by 1) applying molecular analyses (i.e. lipids) to better discriminate the source materials, 2) surveying the site in the long term, with the present study as the “time zero", to monitor indices of vascular plant colonization. 
Finally, these results highlight issues that need to be addressed to fully assess the impact of Sphagnum peatland invasion by vascular plants: 1) test for the priming effect induced by labile $\mathrm{C}$ injection in deep peat, 2) test the $\mathrm{C}$ overflow hypothesis in nutrient-limiting conditions.

\section{ACKNOWLEDGEMENTS}

This paper is a contribution to the research conducted at the OSUC (Observatoire des Sciences de l’Univers en région Centre). Financial support was provided by a Conseil General du Loiret grant to S. Gogo. The authors gratefully acknowledge M. Hatton, R. Boscardin and E. Rivoire for analytical assistance and J.R. Disnar and C. Défarge for advice regarding Rock Eval pyrolysis and spectrophometer analyses. The authors are also grateful to the reviewers for their constructive comments and helpful suggestions on an earlier version of the manuscript.

\section{REFERENCES}

Bartsch I, Moore TR (1985) A preliminary investigation of primary production and decomposition in four peatlands near Schefferville, Québec. Can J Botany 63:1241-1248

Berendse F (1998) Effects of dominant plant species on soils during succession in nutrient-poor ecosystems. Biogeochemistry 42:73-88 
Bergman I, Svensson BH, Nilsson M (1998) Regulation of methane production in a Swedish mire by $\mathrm{pH}$, temperature and substrate. Soil Biol and Biochem 31:1867-1877

Bourdon S, Laggoun-Défarge F, Maman O et al (2000) Organic matter sources and early diagenetic degradation in a tropical peaty marsh (Tritrivakely, Madagascar). Implications for environmental reconstruction during the SubAtlantic. Org Geochem 31:421-38

Bragazza L, Siffi C, Iacumin P et al (2007) Mass loss and nutrient release during litter decay in peatland: The role of microbial adaptability to litter chemistry. Soil Biol and Biochem 39:257-267

van Breemen N (1995) How Sphagnum bogs down other plants. Trends Ecol and Evol 10:270-275

Chamie JPM, Richardson CJ (1978) Decomposition in Northern wetlands. In: Good RE, Whigham DF, Simpson RL (eds) Freshwater wetlands: ecological processes and management potential,. Academic Press, New York

Charman D (2002) Peatlands and Environmental Change. John Wiley \& Sons Ltd, New York 
Clymo RS (1967) Control of cation concentrations, and in particular of $\mathrm{pH}$, in Sphagnum dominated communities. In: Golterman HL, Clymo RS (eds) Chemical Environment in Aquatic Habitat. North Holland, Amsterdam

Clymo RS, Hayward PM (1982) The ecology of Sphagnum. In: Smith AJE (ed) Bryophyte Ecology. Chapman and Hall, New York

Comont L (2006) Etude des processus de stockage de la matière organique et de régénération des tourbières dégradées après exploitation : sites du Russey (Jura français), de la chaux d’Abel (Jura suisse) et de baupte (Cotentin, France). Dissertation, Université d’Orléans.

Comont L, Laggoun-Défarge F, Disnar J-R (2006) Evolution of organic matter indicators in response to major environmental changes: the case of a formerly cutover peatbog (Le Russey, Jura Mountains, France). Org Geochem 37:1736-1751

Conrad R (1996) Soil microorganisms as controllers of atmospheric trace gases $\left(\mathrm{H}_{2}, \mathrm{CO}, \mathrm{CH}_{4}, \mathrm{OCS}, \mathrm{N}_{2} \mathrm{O}\right.$ and NO). Microbiol Rev 60:609-640

Cornelissen JHC, van Bodegom PM, Aerts R et al (2007) Global negative vegetation feedback to climate warming responses of leaf litter decomposition rate in cold biomes. Ecol Lett 10: 619-627

Coulson JC, Butterfield J (1978) An investigation of the biotic factors determining the rates of plant decomposition on blanket bog. J Ecol 66: 631-650 
Disnar J-R, Guillet B, Keravis D et al (2003) Soil organic matter (SOM) characterization by Rock-Eval pyrolysis: scope and limitations. Org Geochem 34:327-343

Disnar J-R, Jacob J, Morched-Issa M et al (2008) Assessment of peat quality by molecular and bulk geochemical analysis : Application to the Holocene record of the Chautagne marsh (Haute Savoir, France). Chem Geol 254:101-112

Dorrepal E, Cornelissen JH, Aerts R (2007) Changing leaf litter feedbacks on plant production across contrasting sub-artic peatland species and growth forms. Oecologia 151:251-261

Espitalié J, Deroo G, Marquis F (1985) La pyrolyse Rock Eval et ses applications. Rev I Fr du Pétrol 40:563-579, 40:755-784, 41:73-89

Fontaine S, Barot S, Barré P (2007) Stability of carbon in deep soil layers controlled by fresh carbon supply. Nature 450:277-280

Ford MSJ (1990) A 10 000-Yr history of acidification of natural ecosystem acidification. Ecol Monogr 67:100-107

Gobat J-M, Grosvernier P, Matthey Y (1986) Les tourbières du Jura suisse. Milieux naturels, modifications humaines, caractères des tourbes, potentiel de régénération. Actes de la Société Jurassienne d'Emulation :213-315 
Gorham E (1991) Northern peatlands: role in the carbon cycle and probable responses to climate warming. Ecol Appl 1:182-195

Hadas A, Parkin TB, Stahl PD (1998) Reduced $\mathrm{CO}_{2}$ release from decomposing wheat straw under N-limiting conditions: simulation of carbon turnover. Eur $\mathrm{J}$ Soil Sci 49:487-494

Hogg P, Squires P, Fitter AH (1995) Acidification, nitrogen deposition and rapid vegetational change in a small valley mire in Yorkshire. Biol conserv 71:143-153

Jacob J (2003) Enregistrement des variations paléoenvironmentales depuis 20000 and dans le Nord Est du Brésil (Lac Caço) par les triterpènes et autres marqueurs organique. Dissertation, Université d’Orléans.

Jacob J, Disnar J-R, Boussafir M et al (2004) Major environmental changes recorded by lacustrine sedimentaryorganic matter since the last glacial maximum near the equator (Lagao do Caço, NE Brazil). Palaeogeog Palaeoclim Palaeoecol 205:183-197

Jones CG, Lawton JH, Schachak M (1994) Organisms as ecosystem engineers. Oikos 69:373-386

Kaila A (1956) Determination of the degree of humification of peat samples. J Agr Sci Finland 28:18-35 
Knies J (2005) Climate-induced changes in sedimentary regimes for organic matter supply on the continental shelf off northern Norway. Geochim Cosmochim Ac 69:4631-4647

Lafargue E, Marquis F, Pillot D (1998) Rock-Eval 6 applications in hydrocarbon exploration, production and soil contamination studies. Rev I Fr Pétrol 53:421437

Laggoun-Défarge F, Mitchell E, Gilbert D et al (2008) Cut-over peatland regeneration assessment using organic matter and microbial indicators (bacteria and testate amoebae). JAppl Ecol 45:716-727

Manzoni A, Porporato A (2009) Soil carbon and nitrogen mineralization: Theory and models across scales. Soil Biol Biochem 41:1355-1379

Minkkinen K, Laine J (1998a) Effect of forest drainage on the peat bulk density of pine mires in Finland. Can J Forest Res 28:178-186

Minkkinen K, Laine J (1998b) Long-term effect of forest drainage on the peat carbon stores of pine mires in Finland. Can J of Forest Res 28:1267-1275

Painter TJ (1991) Lindow man, Tollund man and other peat-bog bodies: the preservative and antimicrobial action of sphagnan, a reactive glycuronoglycan with tanning and sequestering properties. Carbohyd Polym 15: 123-142 
Schlesinger WH (1997) Biogeochemistry: an analysis of global change. Academic Press, San Diego

Sebag D, Disnar J-R, Guillet B et al (2006) Monitoring organic matter dynamics in soil profiles by 'Rock-Eval pyrolysis': bulk characterization and quantification of degradation. Eur J Soil Sci 57:344-355

Statsoft Inc (2008) STATISTICA for Windows Version 8.0. Tulsa Oklahoma, Statsoft, Inc.

Taylor K, Rowland AP, Jones HE (2001) Molinia caerulea (L.) Moench. J Ecol 86:126-144

Tomassen HBM, Smolders AJP, Lamers LPM et al (2003) Stimulated growth of Betula pubescens and Molinia caerulea on ombrotrophic bogs: role of high level of atmospheric nitrogen deposition. J Ecol 91:357-370

Tomassen HBM, Smolders AJP, Limpens J et al (2004) Expansion of invasive species on ombrotrophic bogs: desiccation or high N deposition? J Ecol 41:139150 


\section{FIGURE CAPTIONS}

Figure 1. Map of La Guette peatland (Neuvy-sur-Barangeon, France) showing the location of the studied plots with different vegetation (Open vs Closed) and from the two hydrological areas (Wet vs Dry).

Figure 2. Diagram of a peat core sampled and analyses performed.

Figure 3. Bulk density (a, b, c), PyroPhosphate Index, PPI (d, e, f), and total hemicellulosic sugar content $(\mathrm{g}, \mathrm{h}, \mathrm{i})$ of the uppermost peat $(0$ to $15 \mathrm{~cm})$ from different vegetation plots (Open and Closed) and from the two hydrological areas of the peatland (Wet and Dry). The error bars represent one standard error ( $\mathrm{n}=8)$.

Figure 4. Rock-Eval 6 Oxygen Index (OIRe6) and the ratio of the amount of pyrolysed $\mathrm{CO}_{2}$ to the amount of pyrolysed $\mathrm{CO}\left(\mathrm{OICO}_{2} / \mathrm{OICO}\right)$ of the uppermost peat (0 to $15 \mathrm{~cm}$ depth) from different vegetation plots (Open and Closed). The error bars represent one standard error $(n=8)$.

Figure 5. R400 index and C/S ratio of the uppermost peat (0 to $15 \mathrm{~cm}$ depth) from the two hydrological areas of the peatland (Wet and Dry). The error bars represent one standard error $(n=8)$.

Figure 6. Correlation between R400 and hemicellulosic sugar content of the uppermost peat ( 0 to $15 \mathrm{~cm}$ depth) $(\mathrm{n}=48)$. 
Figure 7. Correlation between $\mathrm{CO}_{2}$ Oxygen Index $\left(\mathrm{OICO}_{2}\right)$ and $\mathrm{CO}$ Oxygen index (OICO) of significant source material litter from La Guette peatland.

Figure 8. Concentrations of total soluble K (a) and S (b) in surface water sampled on May 2008 from the four studied plots in relation to the distance between these plots and the incoming drain of La Guette peatland $(n=3)$.

$\mathrm{WO}=$ Wet Open, $\mathrm{WC}=$ Wet Closed, $\mathrm{DO}=$ Dry Open, $\mathrm{DC}=$ Dry Closed.

Figure 9. Hemicellulosic sugar contents (a) and R400 (b) $(n=4)$ of surface peat (0 $-5 \mathrm{~cm}$ depth) in relation to C/S ( $\mathrm{n}=3)$ of surface water sampled on May 2008 from the four studied plots in La Guette peatland.

WO $=$ Wet Open, $\mathrm{WC}=$ Wet Closed, $\mathrm{DO}=$ Dry Open, DC $=$ Dry Closed. 


\section{TABLES}

Table 1. Annual mean (4 sampling dates, May 2008-March 2009) characteristics of surface water sampled in the four studied plots from La Guette peatland (annual mean \pm standard error, $\mathrm{n}=4$ other than $\mathrm{Al}, \mathrm{n}=1$, not detected in the three other samplings). Data from seasonal monitoring are not shown.

\begin{tabular}{lllll}
\hline & West Open & West Closed & East Open & East Closed \\
\hline $\mathrm{pH}$ & $3.98 \pm 0.21$ & $3.73 \pm 0.22$ & $4.03 \pm 0.34$ & $3.93 \pm 0.23$ \\
Conductivity $\left(\mu \mathrm{S} \mathrm{cm}^{-1}\right)$ & $49.0 \pm 6.47$ & $65.0 \pm 9.36$ & $51.9 \pm 8.25$ & $63.9 \pm 12.6$ \\
$\mathrm{DOC}\left(\mathrm{mg} \mathrm{l}^{-1}\right)$ & $16.2 \pm 0.72$ & $26.5 \pm 1.59$ & $13.9 \pm 1.73$ & $20.9 \pm 1.87$ \\
$\mathrm{~K}\left(\mathrm{mg} \mathrm{l}^{-1}\right)$ & $0.16 \pm 0.03$ & $0.20 \pm 0.04$ & $0.22 \pm 0.02$ & $0.59 \pm 0.14$ \\
$\mathrm{Na}\left(\mathrm{mg} \mathrm{l}^{-1}\right)$ & $2.82 \pm 0.11$ & $2.39 \pm 0.10$ & $2.95 \pm 0.03$ & $3.37 \pm 0.29$ \\
$\mathrm{Mg}\left(\mathrm{mg} \mathrm{l}^{-1}\right)$ & $0.28 \pm 0.06$ & $0.29 \pm 0.03$ & $0.21 \pm 0.01$ & $0.27 \pm 0.03$ \\
$\mathrm{Ca}\left(\mathrm{mg} \mathrm{l}^{-1}\right)$ & $0.71 \pm 0.16$ & $0.76 \pm 0.12$ & $0.45 \pm 0.02$ & $0.73 \pm 0.17$ \\
$\mathrm{Si}\left(\mathrm{mg} \mathrm{l}^{-1}\right)$ & $1.99 \pm 0.24$ & $1.94 \pm 0.33$ & $2.93 \pm 0.32$ & $3.11 \pm 0.55$ \\
$\mathrm{Fe}\left(\mathrm{mg} \mathrm{l}^{-1}\right)$ & $0.42 \pm 0.11$ & $0.88 \pm 0.10$ & $0.52 \pm 0.06$ & $0.66 \pm 0.004$ \\
$\mathrm{Al}\left(\mathrm{mg} \mathrm{l}^{-1}\right)$ & 0.17 & 0.27 & 0.36 & 0.76 \\
\hline
\end{tabular}

Table 2. Chemical composition of the water sampled in the inlet drain on May 2008.

\begin{tabular}{ll}
\hline & Concentration in mg l-1 \\
\hline $\mathrm{N}^{-\mathrm{NO}_{3}{ }^{-}}$ & 0.31 \\
$\mathrm{~N}^{-} \mathrm{NH}_{4}{ }^{+}$ & 0.08 \\
$\mathrm{~N}$ total & 1.14 \\
$\mathrm{~S}$ total & 0.95 \\
$\mathrm{Ca}$ & 3.19 \\
$\mathrm{Fe}$ & 1.40 \\
$\mathrm{~K}$ & 1.89 \\
$\mathrm{Mg}$ & 0.53 \\
$\mathrm{Mn}$ & 0.04 \\
$\mathrm{Na}$ & 4.46 \\
$\mathrm{Si}$ & 4.26 \\
\hline
\end{tabular}


Table 3. Plant cover Percentages of the main plant species in the four studied plots from La Guette peatland.

\begin{tabular}{llllll}
\hline Strata & Species & Wet Open & Wet Closed & Dry Open & Dry Closed \\
\hline Moss & Sphagnum cuspidatum & 35 & 25 & 20 & 50 \\
& Sphagnum rubellum & 25 & 0 & 5 & 0 \\
& Other & 5 & 40 & 15 & 0 \\
\multirow{2}{*}{ Herbaceous } & Molinia caerulea & 20 & 35 & $40^{*}$ & $90^{*}$ \\
& Scheuzeria palustre & 5 & 0 & 0 & 0 \\
& Eriophorum vaginatum & 75 & 55 & 40 & 5 \\
Shrub & Calluna vulgaris & 70 & 25 & 45 & 0 \\
& Erica tetralix & 5 & 40 & 45 & 45 \\
Tree & Betula spp & 0 & 25 & 0 & 15 \\
\hline$*$ in & & & & \\
\end{tabular}

* in the Dry open, M.caerulea is sparse but present everywhere on the plot, whereas in the Dry Closed, it was present as well-developed tussocks 
Table 4. Depth-related evolution of biochemical properties of peat from the four studied plots in La Guette peatland. 4A: Mean ( \pm 1 s.e., $n=4)$ bulk density, carbon, sulfur and nitrogen contents, organic matter amount and Pyrophosphate index (arbitrary units). 4B: Rock Eval parameters : Hydrogen Index, $\mathrm{OICO}_{2}\left(\mathrm{CO}_{2}\right.$ released during pyrolysis, relative to TOC), OICO (CO released during pyrolysis, relative to TOC), OIRe6 $\left(\mathrm{O}_{2}\right.$ released as $\mathrm{CO}$ and $\mathrm{CO}_{2}$ during pyrolysis, relative to TOC), R400 ratio (the part of the S2 signal produced below $400^{\circ} \mathrm{C}$ compared to the total S2 signal) and $\mathrm{OICO}_{2} / \mathrm{OICO}$ ratio.

Table 4A.

\begin{tabular}{|c|c|c|c|c|c|c|c|c|c|c|c|c|c|c|c|c|c|c|}
\hline \multirow{2}{*}{$\begin{array}{l}\text { Plot } \\
\text { Wet Open }\end{array}$} & \multirow{2}{*}{$\begin{array}{l}\text { depth }(\mathrm{cm}) \\
0-5\end{array}$} & \multicolumn{2}{|c|}{$\begin{array}{l}\text { bulk density } \\
\left(\mathrm{g} \mathrm{cm}^{-3}\right)\end{array}$} & \multicolumn{3}{|c|}{$\mathrm{C}\left(\mathrm{mg} \mathrm{g}^{-1}\right)$} & \multicolumn{3}{|c|}{$\mathrm{S}\left(\mathrm{mg} \mathrm{g}^{-1}\right)$} & \multicolumn{3}{|c|}{$\mathrm{N}\left(\mathrm{mg} \mathrm{g}^{-1}\right)$} & \multicolumn{3}{|c|}{ MO (\%) } & \multicolumn{3}{|l|}{ PPI } \\
\hline & & 0.05 & \pm 0.02 & 423 & \pm & 15.2 & 2.19 & \pm & 0.61 & 9.8 & \pm & 2.74 & 89 & \pm & 2.9 & 14 & \pm & 4.3 \\
\hline & $5-10$ & 0.10 & \pm 0.02 & 413 & \pm & 19.6 & 3.50 & \pm & 0.22 & 13.1 & \pm & 3.08 & 83 & \pm & 2.6 & 27 & \pm & 3.4 \\
\hline & $10-15$ & 0.16 & \pm 0.01 & 403 & \pm & 21.5 & 3.01 & \pm & 0.37 & 13.5 & \pm & 1.54 & 81 & \pm & 1.9 & 41 & \pm & 7.8 \\
\hline & $15-20$ & 0.18 & \pm 0.03 & 453 & \pm & 10.5 & 2.53 & \pm & 0.28 & 15.0 & \pm & 0.90 & 88 & \pm & 1.5 & 50 & \pm & 19.0 \\
\hline & $20-25$ & 0.20 & \pm 0.02 & 462 & \pm & 9.6 & 1.78 & \pm & 0.06 & 13.0 & \pm & 2.13 & 86 & \pm & 1.5 & 88 & \pm & 13.0 \\
\hline & $25-30$ & 0.32 & \pm 0.03 & 441 & \pm & 15.7 & 1.22 & \pm & 0.14 & 10.9 & \pm & 1.97 & 78 & \pm & 2.4 & 104 & \pm & 11.3 \\
\hline & $30-35$ & 0.24 & \pm 0.03 & 510 & \pm & 27.9 & 1.52 & \pm & 0.09 & 8.9 & \pm & 1.43 & 87 & \pm & 3.3 & 121 & \pm & 11.5 \\
\hline & $35-40$ & 0.17 & \pm 0.03 & 520 & \pm & 20.1 & 1.51 & \pm & 0.18 & 10.1 & \pm & 1.94 & 90 & \pm & 4.7 & 137 & \pm & 23.1 \\
\hline & $40-45$ & 0.13 & \pm 0.01 & 499 & \pm & 10.1 & 2.34 & \pm & 0.27 & 9.3 & \pm & 2.42 & 92 & \pm & 2.0 & 109 & \pm & 11.6 \\
\hline & $45-50$ & 0.12 & \pm 0.03 & 403 & \pm & 54.8 & 2.05 & \pm & 0.44 & 6.7 & \pm & 0.58 & 74 & \pm & 10.0 & 73 & \pm & 7.2 \\
\hline \multirow[t]{10}{*}{ Wet Closed } & $0-5$ & 0.08 & \pm 0.01 & 409 & \pm & 9.5 & 3.48 & \pm & 0.17 & 13.1 & \pm & 1.22 & 81 & \pm & 0.5 & 23 & \pm & 2.3 \\
\hline & $5-10$ & 0.12 & \pm 0.01 & 436 & \pm & 15.8 & 3.21 & \pm & 0.15 & 15.5 & \pm & 0.91 & 86 & \pm & 2.0 & 24 & \pm & 2.4 \\
\hline & $10-15$ & 0.19 & \pm 0.01 & 417 & \pm & 9.2 & 2.52 & \pm & 0.12 & 13.9 & \pm & 1.19 & 80 & \pm & 1.6 & 43 & \pm & 9.2 \\
\hline & $15-20$ & 0.27 & \pm 0.02 & 350 & \pm & 7.7 & 1.72 & \pm & 0.05 & 9.7 & \pm & 0.73 & 64 & \pm & 1.9 & 67 & \pm & 6.6 \\
\hline & $20-25$ & 0.35 & \pm 0.02 & 317 & \pm & 30.4 & 1.28 & \pm & 0.16 & 8.1 & \pm & 0.71 & 56 & \pm & 4.1 & 85 & \pm & 6.9 \\
\hline & $25-30$ & 0.37 & \pm 0.07 & 345 & \pm & 56.6 & 1.23 & \pm & 0.41 & 6.7 & \pm & 1.42 & 57 & \pm & 9.4 & 107 & \pm & 9.5 \\
\hline & $30-35$ & 0.21 & $\pm \quad 0.01$ & 423 & \pm & 69.1 & 1.53 & \pm & 0.22 & 6.6 & \pm & 1.51 & 70 & \pm & 10.9 & 104 & \pm & 15.8 \\
\hline & $35-40$ & 0.33 & \pm 0.05 & 176 & \pm & 38.9 & 1.00 & \pm & 0.28 & 2.0 & \pm & 1.07 & 32 & \pm & 7.1 & 50 & \pm & 11.2 \\
\hline & $40-45$ & 0.85 & $\pm \quad 0.11$ & 45 & \pm & 7.7 & 0.16 & \pm & 0.07 & 0.0 & \pm & 0.00 & 9 & \pm & 1.4 & 13 & \pm & 1.7 \\
\hline & $45-50$ & 0.84 & $\pm \quad 0.14$ & 40 & \pm & 7.1 & 0.19 & \pm & 0.05 & 0.0 & \pm & 0.00 & 8 & \pm & 1.3 & 14 & \pm & 1.2 \\
\hline \multirow[t]{10}{*}{ Dry Open } & $0-5$ & 0.03 & $\pm \quad 0.01$ & 410 & \pm & 16.6 & 3.83 & \pm & 0.39 & 13.9 & \pm & 1.09 & 86 & \pm & 3.6 & 17 & \pm & 1.0 \\
\hline & $5-10$ & 0.04 & \pm 0.00 & 399 & \pm & 17.7 & 4.04 & \pm & 0.11 & 15.1 & \pm & 0.61 & 84 & \pm & 2.5 & 17 & \pm & 1.4 \\
\hline & $10-15$ & 0.10 & $\pm \quad 0.01$ & 361 & \pm & 30.7 & 3.60 & \pm & 0.15 & 15.7 & \pm & 0.69 & 75 & \pm & 5.4 & 19 & \pm & 2.9 \\
\hline & $15-20$ & 0.17 & \pm 0.03 & 373 & \pm & 24.2 & 3.06 & \pm & 0.21 & 18.9 & \pm & 1.08 & 73 & \pm & 5.2 & 31 & \pm & 6.3 \\
\hline & $20-25$ & 0.21 & \pm 0.02 & 358 & \pm & 21.3 & 2.49 & \pm & 0.13 & 18.1 & \pm & 0.75 & 70 & \pm & 5.0 & 42 & \pm & 5.5 \\
\hline & $25-30$ & 0.26 & \pm 0.01 & 339 & \pm & 15.6 & 2.17 & \pm & 0.08 & 16.5 & \pm & 0.99 & 64 & \pm & 2.9 & 63 & \pm & 2.5 \\
\hline & $30-35$ & 0.26 & \pm 0.01 & 318 & \pm & 21.4 & 1.96 & \pm & 0.13 & 14.8 & \pm & 0.85 & 60 & \pm & 4.4 & 69 & \pm & 2.1 \\
\hline & $35-40$ & 0.31 & \pm 0.03 & 273 & \pm & 32.7 & 1.55 & \pm & 0.20 & 12.5 & \pm & 1.59 & 50 & \pm & 5.1 & 76 & \pm & 5.8 \\
\hline & $40-45$ & 0.38 & \pm 0.05 & 195 & \pm & 50.6 & 1.12 & \pm & 0.24 & 9.1 & \pm & 2.03 & 37 & \pm & 8.0 & 61 & \pm & 7.3 \\
\hline & $45-50$ & 0.51 & \pm 0.14 & 66 & \pm & 25.3 & 0.39 & \pm & 0.15 & 3.0 & \pm & 1.33 & 21 & \pm & 2.6 & 35 & \pm & 3.2 \\
\hline \multirow[t]{10}{*}{ Dry Closed } & $0-5$ & 0.07 & \pm 0.01 & 412 & \pm & 6.1 & 4.33 & \pm & 0.38 & 15.4 & \pm & 0.71 & 85 & \pm & 0.6 & 24 & \pm & 1.6 \\
\hline & $5-10$ & 0.09 & \pm 0.01 & 389 & \pm & 7.9 & 4.61 & \pm & 0.28 & 17.5 & \pm & 0.77 & 81 & \pm & 1.7 & 25 & \pm & 3.0 \\
\hline & $10-15$ & 0.17 & \pm 0.01 & 379 & \pm & 7.7 & 3.47 & \pm & 0.39 & 17.5 & \pm & 1.11 & 75 & \pm & 1.8 & 31 & \pm & 5.7 \\
\hline & $15-20$ & 0.21 & \pm 0.01 & 397 & \pm & 8.3 & 2.81 & \pm & 0.19 & 18.1 & \pm & 0.57 & 77 & \pm & 0.7 & 40 & \pm & 7.3 \\
\hline & $20-25$ & 0.20 & \pm 0.00 & 402 & \pm & 13.3 & 2.83 & \pm & 0.18 & 18.0 & \pm & 0.62 & 77 & \pm & 2.2 & 45 & \pm & 4.4 \\
\hline & $25-30$ & 0.19 & \pm 0.02 & 426 & \pm & 16.5 & 2.71 & \pm & 0.10 & 18.2 & \pm & 1.58 & 79 & \pm & 2.6 & 51 & \pm & 7.8 \\
\hline & $30-35$ & 0.18 & \pm 0.01 & 417 & \pm & 16.3 & 2.65 & \pm & 0.20 & 16.3 & \pm & 1.49 & 77 & \pm & 2.8 & 60 & \pm & 8.6 \\
\hline & $35-40$ & 0.18 & $\pm \quad 0.01$ & 399 & \pm & 9.9 & 2.35 & \pm & 0.13 & 14.6 & \pm & 1.07 & 72 & \pm & 1.9 & 90 & \pm & 7.7 \\
\hline & $40-45$ & 0.17 & $\pm \quad 0.01$ & 424 & \pm & 8.8 & 2.30 & \pm & 0.20 & 14.5 & \pm & 0.89 & 75 & \pm & 0.7 & 93 & \pm & 2.8 \\
\hline & $45-50$ & 0.18 & $\pm \quad 0.01$ & 388 & \pm & 41.5 & 2.17 & \pm & 0.29 & 12.1 & \pm & 1.66 & 69 & \pm & 6.6 & 96 & \pm & 7.4 \\
\hline
\end{tabular}


Table 4B.

\begin{tabular}{|c|c|c|c|c|c|c|c|c|c|c|c|c|c|c|c|c|c|c|c|}
\hline \multirow{2}{*}{$\begin{array}{l}\text { Plot } \\
\text { Wet Open }\end{array}$} & \multirow{2}{*}{$\begin{array}{l}\text { depth (cm) } \\
0-5\end{array}$} & \multicolumn{3}{|c|}{$\begin{array}{l}\mathrm{HI} \text { (mg HC } \\
\left.\mathrm{g}^{-1} \mathrm{TOC}\right)\end{array}$} & \multicolumn{3}{|c|}{$\begin{array}{r}\mathrm{OICO}_{2}\left(\mathrm{mg} \mathrm{CO} \mathrm{CO}_{2}\right. \\
\left.\mathrm{g}^{-1} \mathrm{TOC}\right) \\
\end{array}$} & \multicolumn{3}{|c|}{$\begin{array}{r}\text { OI CO (mg CO } \\
g^{-1} \text { TOC) }\end{array}$} & \multicolumn{3}{|c|}{$\begin{array}{r}\text { OI Re6 (mg O } \\
\mathrm{g}^{-1} \text { TOC) }\end{array}$} & \multicolumn{3}{|l|}{ R400 } & \multicolumn{3}{|c|}{$\mathrm{OICO}_{2} / \mathrm{OICO}$} \\
\hline & & 383 & \pm & 22.8 & 217 & \pm & 17.1 & 63 & \pm & 3.9 & 194 & \pm & 14.0 & 0.54 & \pm & 0.01 & 3.42 & \pm & 0.21 \\
\hline & $5-10$ & 395 & \pm & 15.3 & 185 & \pm & 14.4 & 48 & \pm & 1.1 & 162 & \pm & 11.0 & 0.50 & \pm & 0.01 & 3.86 & \pm & 0.25 \\
\hline & $10-15$ & 423 & \pm & 17.5 & 173 & \pm & 13.5 & 45 & \pm & 1.1 & 152 & \pm & 9.8 & 0.48 & \pm & 0.01 & 3.90 & \pm & 0.32 \\
\hline & $15-20$ & 400 & \pm & 13.2 & 180 & \pm & 16.6 & 44 & \pm & 3.3 & 156 & \pm & 13.3 & 0.46 & \pm & 0.02 & 4.05 & \pm & 0.30 \\
\hline & $20-25$ & 418 & \pm & 19.8 & 158 & \pm & 14.7 & 45 & \pm & 2.2 & 141 & \pm & 11.9 & 0.40 & \pm & 0.02 & 3.46 & \pm & 0.18 \\
\hline & $25-30$ & 393 & \pm & 46.5 & 139 & \pm & 16.2 & 45 & \pm & 4.2 & 127 & \pm & 13.6 & 0.34 & \pm & 0.02 & 3.11 & \pm & 0.22 \\
\hline & $30-35$ & 437 & \pm & 38.2 & 147 & \pm & 22.7 & 49 & \pm & 7.4 & 135 & \pm & 20.4 & 0.34 & \pm & 0.02 & 3.03 & \pm & 0.19 \\
\hline & $35-40$ & 393 & \pm & 40.2 & 148 & \pm & 19.0 & 50 & \pm & 5.6 & 136 & \pm & 17.0 & 0.35 & \pm & 0.01 & 2.98 & \pm & 0.07 \\
\hline & $40-45$ & 325 & \pm & 17.7 & 179 & \pm & 17.3 & 66 & \pm & 6.8 & 168 & \pm & 16.3 & 0.38 & \pm & 0.01 & 2.70 & \pm & 0.09 \\
\hline & $45-50$ & 323 & \pm & 17.8 & 146 & \pm & 9.1 & 55 & \pm & 1.3 & 137 & \pm & 7.3 & 0.38 & \pm & 0.01 & 2.65 & \pm & 0.11 \\
\hline \multirow[t]{10}{*}{ Wet Closed } & $0-5$ & 338 & \pm & 13.1 & 146 & \pm & 3.2 & 65 & \pm & 6.2 & 143 & \pm & 3.7 & 0.51 & \pm & 0.01 & 2.32 & \pm & 0.24 \\
\hline & $5-10$ & 446 & \pm & 6.0 & 146 & \pm & 2.7 & 51 & \pm & 5.6 & 135 & \pm & 1.9 & 0.52 & \pm & 0.01 & 2.98 & \pm & 0.37 \\
\hline & $10-15$ & 465 & \pm & 5.2 & 125 & \pm & 5.6 & 57 & \pm & 7.6 & 124 & \pm & 6.2 & 0.44 & \pm & 0.02 & 2.30 & \pm & 0.32 \\
\hline & $15-20$ & 454 & \pm & 6.9 & 116 & \pm & 5.9 & 54 & \pm & 4.7 & 115 & \pm & 3.6 & 0.38 & \pm & 0.01 & 2.23 & \pm & 0.28 \\
\hline & $20-25$ & 452 & \pm & 7.1 & 97 & \pm & 2.8 & 54 & \pm & 3.4 & 101 & \pm & 2.0 & 0.34 & \pm & 0.01 & 1.82 & \pm & 0.17 \\
\hline & $25-30$ & 456 & \pm & 8.2 & 76 & \pm & 9.4 & 46 & \pm & 7.8 & 81 & \pm & 11.2 & 0.34 & \pm & 0.01 & 1.69 & \pm & 0.11 \\
\hline & $30-35$ & 485 & \pm & 25.5 & 86 & \pm & 3.4 & 53 & \pm & 9.3 & 93 & \pm & 7.4 & 0.33 & \pm & 0.01 & 1.75 & \pm & 0.25 \\
\hline & $35-40$ & 408 & \pm & 16.9 & 91 & \pm & 1.5 & 63 & \pm & 7.9 & 102 & \pm & 5.4 & 0.35 & \pm & 0.01 & 1.50 & \pm & 0.17 \\
\hline & $40-45$ & 371 & \pm & 11.6 & 82 & \pm & 2.3 & 67 & \pm & 5.2 & 97 & \pm & 1.9 & 0.40 & \pm & 0.00 & 1.26 & \pm & 0.13 \\
\hline & $45-50$ & 341 & \pm & 19.2 & 78 & \pm & 2.2 & 65 & \pm & 4.1 & 94 & \pm & 2.2 & 0.40 & \pm & 0.01 & 1.20 & \pm & 0.10 \\
\hline \multirow[t]{10}{*}{ Dry Open } & $0-5$ & 385 & \pm & 5.0 & 185 & \pm & 8.1 & 54 & \pm & 3.1 & 165 & \pm & 5.7 & 0.56 & \pm & 0.01 & 3.45 & \pm & 0.28 \\
\hline & $5-10$ & 377 & \pm & 7.9 & 186 & \pm & 4.4 & 53 & \pm & 2.5 & 166 & \pm & 2.0 & 0.56 & \pm & 0.01 & 3.54 & \pm & 0.24 \\
\hline & $10-15$ & 428 & \pm & 11.9 & 164 & \pm & 3.0 & 43 & \pm & 3.1 & 144 & \pm & 2.6 & 0.52 & \pm & 0.03 & 3.83 & \pm & 0.29 \\
\hline & $15-20$ & 449 & \pm & 19.8 & 155 & \pm & 5.8 & 41 & \pm & 1.9 & 136 & \pm & 5.0 & 0.50 & \pm & 0.01 & 3.82 & \pm & 0.15 \\
\hline & $20-25$ & 457 & \pm & 11.2 & 147 & \pm & 5.5 & 40 & \pm & 1.8 & 129 & \pm & 4.3 & 0.46 & \pm & 0.01 & 3.72 & \pm & 0.19 \\
\hline & $25-30$ & 463 & \pm & 2.7 & 133 & \pm & 4.2 & 39 & \pm & 2.2 & 119 & \pm & 3.7 & 0.42 & \pm & 0.01 & 3.45 & \pm & 0.19 \\
\hline & $30-35$ & 438 & \pm & 8.6 & 112 & \pm & 13.6 & 36 & \pm & 1.5 & 102 & \pm & 10.0 & 0.38 & \pm & 0.01 & 3.14 & \pm & 0.40 \\
\hline & $35-40$ & 398 & \pm & 26.4 & 108 & \pm & 2.7 & 39 & \pm & 2.1 & 101 & \pm & 2.1 & 0.35 & \pm & 0.00 & 2.82 & \pm & 0.19 \\
\hline & $40-45$ & 332 & \pm & 45.8 & 103 & \pm & 3.9 & 42 & \pm & 3.2 & 99 & \pm & 4.3 & 0.31 & \pm & 0.02 & 2.48 & \pm & 0.16 \\
\hline & $45-50$ & 286 & \pm & 7.3 & 96 & \pm & 1.7 & 47 & \pm & 2.4 & 97 & \pm & 1.4 & 0.28 & \pm & 0.02 & 2.08 & \pm & 0.12 \\
\hline \multirow[t]{10}{*}{ Dry Closed } & $0-5$ & 349 & \pm & 20.7 & 154 & \pm & 12.3 & 69 & \pm & 0.9 & 152 & \pm & 8.4 & 0.56 & \pm & 0.02 & 2.22 & \pm & 0.20 \\
\hline & $5-10$ & 388 & \pm & 4.5 & 147 & \pm & 12.6 & 64 & \pm & 2.9 & 143 & \pm & 10.7 & 0.53 & \pm & 0.01 & 2.30 & \pm & 0.12 \\
\hline & $10-15$ & 421 & \pm & 1.6 & 134 & \pm & 11.5 & 55 & \pm & 1.2 & 129 & \pm & 9.0 & 0.49 & \pm & 0.01 & 2.41 & \pm & 0.17 \\
\hline & $15-20$ & 435 & \pm & 1.8 & 128 & \pm & 13.2 & 50 & \pm & 3.4 & 122 & \pm & 10.7 & 0.46 & \pm & 0.01 & 2.57 & \pm & 0.25 \\
\hline & $20-25$ & 428 & \pm & 14.3 & 108 & \pm & 14.9 & 50 & \pm & 3.6 & 107 & \pm & 12.4 & 0.45 & \pm & 0.01 & 2.16 & \pm & 0.21 \\
\hline & $25-30$ & 404 & \pm & 14.8 & 105 & \pm & 16.0 & 47 & \pm & 3.6 & 103 & \pm & 13.1 & 0.43 & \pm & 0.01 & 2.22 & \pm & 0.25 \\
\hline & $30-35$ & 399 & \pm & 11.0 & 96 & \pm & 15.1 & 46 & \pm & 4.0 & 97 & \pm & 12.4 & 0.42 & \pm & 0.01 & 2.08 & \pm & 0.25 \\
\hline & $35-40$ & 406 & \pm & 9.0 & 85 & \pm & 13.1 & 44 & \pm & 2.6 & 87 & \pm & 10.9 & 0.39 & \pm & 0.01 & 1.90 & \pm & 0.20 \\
\hline & $40-45$ & 447 & \pm & 5.7 & 77 & \pm & 12.3 & 43 & \pm & 3.0 & 81 & \pm & 10.6 & 0.35 & \pm & 0.01 & 1.78 & \pm & 0.17 \\
\hline & $45-50$ & 400 & \pm & 17.7 & 76 & \pm & 9.9 & 46 & \pm & 1.4 & 81 & \pm & 7.4 & 0.36 & \pm & 0.02 & 1.67 & \pm & 0.21 \\
\hline
\end{tabular}


Table 5. Statistical results of the two-way ANOVAs for each response variable.

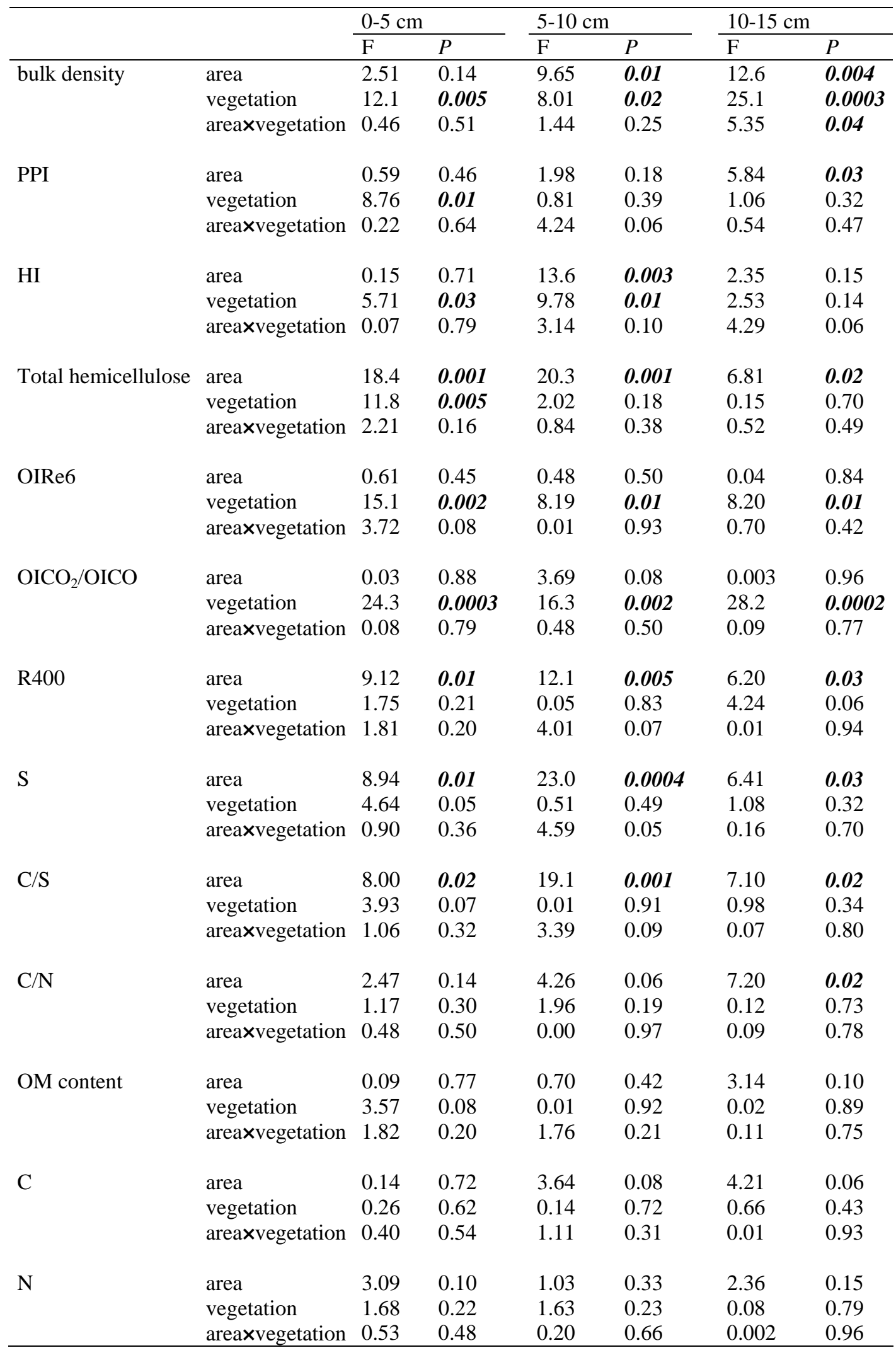


1 Table 6. Litter biochemical indicators of the dominant mosses (Sphagnum spp.) and vascular plants (Betula verrucosa. and Molinia caerulea) in

2 La Guette peatland.

3 Sphagnum litter corresponds to the white-yellow part below the green or red photosynthetic part.

\begin{tabular}{|c|c|c|c|c|c|c|c|c|c|c|}
\hline & OM (\%) & $\mathrm{C}\left(\mathrm{mg} \mathrm{g}^{-1}\right)$ & $\mathrm{N}\left(\mathrm{mg} \mathrm{g}^{-1}\right)$ & $\mathrm{S}\left(\mathrm{mg} \mathrm{g}^{-1}\right)$ & $\begin{array}{l}\text { HI (mg HC g-1 } \\
\text { TOC) }\end{array}$ & 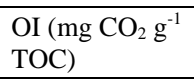 & $\begin{array}{l}\text { OICO (mg CO g } \\
\text { TOC) }\end{array}$ & $\begin{array}{l}\text { OIRe6 (mg O } \mathrm{O} \mathrm{g}^{-1} \\
\text { TOC) }\end{array}$ & R400 & $\mathrm{OICO}_{2} / \mathrm{OICO}$ \\
\hline Sphagnum cuspidatum litter & 98.5 & 428.2 & 2.2 & 0.61 & 404 & 252 & 79 & 228 & 0.76 & 3.20 \\
\hline Sphagnum rubellum litter & 98.1 & 431.7 & 2.2 & 0.53 & 460 & 301 & 86 & 268 & 0.73 & 3.52 \\
\hline Senescent leaves of Betula verrucosa & 96.8 & 501.3 & 6.2 & 0.59 & 544 & 135 & 105 & 158 & 0.63 & 1.29 \\
\hline Branches of Betula verrucosa & $\mathrm{nm}$ & $\mathrm{nm}$ & $\mathrm{nm}$ & $\mathrm{nm}$ & 506 & 133 & 130 & 171 & 0.63 & 1.02 \\
\hline Roots of Betula verrucosa & $\mathrm{nm}$ & $\mathrm{nm}$ & $\mathrm{nm}$ & $\mathrm{nm}$ & 459 & 143 & 71 & 145 & 0.66 & 2.01 \\
\hline Molinia caerulea litter & 92.9 & 446.7 & 1.0 & 0.45 & 635 & 150 & 139 & 188 & 0.78 & 1.08 \\
\hline Shoots of Molina caerulea & $\mathrm{nm}$ & 469.2 & nd & 0.48 & 576 & 126 & 61 & 126 & 0.83 & 2.07 \\
\hline Roots of Molinia caerulea & $\mathrm{nm}$ & $\mathrm{nm}$ & $\mathrm{nm}$ & $\mathrm{nm}$ & 534 & 214 & 157 & 245 & 0.83 & 1.36 \\
\hline
\end{tabular}

$\mathrm{nm}=$ not measured

5

nd $=$ not detected 